\title{
PERCEIVED SERVICE ORIENTATION, ECONOMIC FACTORS, PSYCHOLOGICAL FACTORS AND TAX COMPLIANCE: EVIDENCE FROM NIGERIAN SMES
}

\author{
AUGUSTINE AYUBA \\ Faculty of Social \& Management Science \\ Kaduna State University \\ NATRAH SAAD \\ ZAIMAH ZAINOL ARIFFIN \\ Tunku Puteri Intan Safinaz \\ School of Accountancy \\ Universiti Utara Malaysia
}

\begin{abstract}
This study examined the influence of economic and, psychological factors, as well as the moderating role of perceived service orientation on the tax compliance of Nigerian SMEs owners / managers. Three hundred and twenty one SME owners /managers participated in the survey. The Partial Least Squares (PLS) path modeling was employed to analyze the data. The results showed that the probability of detection, incentives, and the public governance quality had significant positive effects on tax compliance, while tax complexity had a significant negative effect on tax compliance. On the contrary, the results showed that tax rates and tax knowledge had no significant effect on tax compliance. Furthermore, the findings of the moderating effect revealed that perceived service orientation only moderated tax rates and incentives, while in moderating effect was discovered on the relationship between the probability of detection, tax complexity, tax knowledge and public governance quality. The implications for tax revenue authorities and other policy-makers were also discussed.
\end{abstract}

Keywords: Nigerian SMEs, economic factors, psychological factors, perceived service orientation, tax compliance

\section{Introduction}

Over the past decades, there has been a growing concern among policy-makers and scholars on the issue of tax compliance globally because tax compliance issues affect both developed, emerging and developing economies (Hindriks \& Weber, 2008). In recent times, there has been a contention by scholars that cases of tax compliance were more pronounced in developing countries than that of developed economies (Mas'ud, Aliyu \& Gambo, 2014). However, Ayuba, Saad and Ariffin (2015) argued that the issue of tax compliance cut across international boundaries. In the past, many studies focused on the combination of economic factors that influenced tax compliance (e.g. Allingham \& Sandmo, 1972; Ayuba, Saad \& Ariffin, 2016; Becker, 1968; Chris, Coleen \& David, 2000; Fischer, Wartick \& Mark, 1992; Manaf, Hasseldine \& Hodges, 2005; Mustafa, 1997; Nur - tegin, 2008; Palil, Hamid \& Hanafiah, 2013; Saad, 2014; Torgler, 2005). Likewise, psychological factors too were shown to be important determinants of tax compliance (Ayuba, Saad \& Ariffin, 2015). In the 
literature, incentives i.e. positive inducement, tax knowledge, and public governance quality (PGQ), have been widely discussed (Alabede, Ariffin \& Kamil, 2011; Chris, Coleen \& David, 2000; Manaf, 2004; Mustafa, 1997; Richardson, 2006; Saad, 2014).

In the Nigerian setting, studies on the phenomenon of tax compliance are very few. For instance, Alabede (2012) studied the factors influencing tax compliance behavior in Nigeria. However, the study was limited in coverage. In the same vein, Atawodi and Ojeka (2012) focused on the tax compliance behavior of SMEs taxpayers in the North - Central Nigeria. The authors' scope was only limited to a single local government (i.e. Zaria). However, there is a dearth of empirical research that conceptualizes and proposes the moderating role of perceived service orientation on the relationship between economic factors, psychological factors and tax compliance of SMEs because taxpayers who perceived greater service will be more willing to pay their taxes (Gangl, Muehlbacher, de Groot, Goslinga, Hofmann, Kogler, Antonides \& Kirchler, 2013). This was motivated by the recommendation of Stefura $(2011,2012)$ for the need of studying more psychological and other non-economic variables.

In practical terms, there were lingering cases of tax compliance across countries. For instance, BBC news (2013) reported cases of low level of tax payment by the Amazon, Google and Starbucks units in the United Kingdom (UK). These companies who separately recorded a turnover of 3.35 billion and 395 million UK pounds, made available only 1.8 million, 6 million and 400 million UK pounds as tax. In another related development, reports available in the Asian axis also disclosed that, the Malaysian Inland Revenue Board was able to solve 1.9 million cases of tax litigation in 2012. That alone led the board to recoup a whooping sum of RM2.95 million (New Sabah Times English, 2013).

In Nigeria, a growing number of reports have indicated that issues of tax compliance are on the increase. For example, a recent report issued by the global index of economic and social development that annually compares tax system globally revealed that the country is going down the bottom rungs of this index (Paying Taxes, 2015). Furthermore, Tanko (2014) disclosed that in Kaduna State alone over N18 billion ( $\$ 112.5$ million) was lost due to unpaid taxes in 2013. This act culminated in the closure of twenty-five (25) Small and Medium Enterprises (SMEs). In the same vein, the Federal Inland Revenue Services (FIRS), in November 2014, reported that over N110 million was lost in Jos (Plateau State) owing to tax related issues which resulted in the sealing off of a microfinance bank and 16 SMEs (Abimaje, 2014). To fill in this gap, our paper delivers two important contributions to the tax compliance literature. Firstly, we provide empirical support for the direct relationship between tax rates, the probability of detection, tax complexity, tax knowledge, incentive (positive inducement), public governance quality, and tax compliance. Secondly, by means of introducing the moderating effect of perceived service orientation on the above relationship, this paper provides assistance to the State's Board of Internal Revenue Services, Federal Inland Revenue Services, the academia, and other policy-makers in making a reasoned decision on the combined factors that could help in explaining the paradox of tax compliance.

The paper is organized as follows. The next section analyzes the extant literature on tax compliance as well as deriving the focal hypotheses of this research. The subsequent section describes the methods employed in the study. The fourth section presents the main results obtained in the study. The fifth section provides a discussion of the main findings. The final section identifies possible limitations and addresses avenues for further research.

\section{Review Of Related Literature}

\section{Tax compliance}

Unlike other concepts, the meaning of tax compliance can be viewed as a phenomenon that changes over time (Ayuba, Saad \& Ariffin, 2015). In simple terms, Song and Yarbrough (1978) defined tax compliance as the taxpayers' ability and willingness to comply with the relevant tax laws and regulations which are determined by ethics, legal environment and other factors at a given time and place. 
Over the years, several tax authorities have not been left out in suggesting appropriate definition for tax compliance. The Inland Revenue Board (IRB) (2009), and the Australian Tax Office (ATO) (2009) distinctly defined tax compliance as the taxpayers' ability and willingness to obey the tax laws, declare their actual income annually and pay the right amount of taxes on the due date. In other words, tax compliance can be defined as the ability to comply with the reporting requirements (Roth, Scholz \& Witte, 1989), which invariably means that, the entity files all their tax returns at the appropriate time, and the returns accurately report tax liability in line with the internal revenue code, regulations and court decisions applicable at the time the returns are filed. Alternatively, James and Alley (2002) defined tax compliance as the ability of taxable entities to respond in relation to the spirit as well as the letter of relevant tax laws without the administration or application of enforcement. They consider tax compliance in terms of the tax gap, i.e. the difference between the true entity's income tax liability and that which is finally collected by either voluntary payment or by enforcement.

Consequently, few studies also viewed tax compliance from another dimension. For instance, Palil and Mustapha (2011) viewed tax compliance as the willingness of the taxpayers to abide by the tax laws, declare the correct incomes, claim the correct deductions, relief and rebates and pay all taxes on time. Recently, Geibart (2014) conceived tax compliance as a means of navigating a maze of rules, regulations, exceptions and exemptions which can leave a tax agent confused, disorientated and often lost when they reach a frustrating dead end. Thus, considering the context of which this study is being conducted, tax compliance could be seen as the taxpayers' ability and willingness to obey the tax laws, declare their actual incomes and pay the right amount of taxes on the due date to the appropriate relevant authority or jurisdiction (Ayuba, Saad \& Ariffin, 2016).

\section{Tax Rate and Tax Compliance}

Previous studies on the relationship between tax rates and tax compliance show that, an increase in the tax rates always leads to an increase in tax compliance (Allingham \& Sandmo, 1972; Hai \& See, 2011). In the same vein, Alm, Sanchez, and De Juan (1995) further showed that higher tax rate leads to a decrease in tax evasion which invariably increases the compliance level. On the contrary, Clotfelter (1983), Slemrod (1985), Pommerehne and Weck-Hannemann (1996), in separate but related studies indicated that increasing the rate of tax lead to a decrease in the level of compliance. Furthermore, Mas'ud, Aliyu and Gambo (2014) found that a negative relationship exists between tax rates and tax compliance.

However, Alm, Sanchez and De Juan, (1995) and Feinstein (1991) found a negative relationship between tax rates and tax evasion as well as a positive relationship between tax rates and tax compliance. While, more evidence revealed high tax rates to be positively related to tax evasion as well as negatively related to tax compliance (Ali, Cecil \& Knoblett, 2001; Christian \& Gupta, 1993). Hence, Modugu and Anyaduba (2014) and Richardson (2006) recently showed that tax rate does predict either positive or negative relationships on tax compliance. Though, a quite number of literature conceived that high tax rate is positively related to tax evasion and negatively related to tax compliance, other studies revealed either no relationship or positive relationship between tax rates and tax compliance. Hence, the following hypothesis is offered:

H1: There is a significant negative relationship between tax rates and tax compliance.

\section{Probability of Detection and Tax Compliance}

It has been documented that, the perceived risk of being detected has a positive relationship with tax compliance (Carnes \& Englebrecht, 1995; Eisenhauer, 2008; Lewis, Carrera, Cullis $\&$ Jones, 2009). Also, when the probability of detection is high, tax compliance may also be high (Alm, 1991). Conversely, Slemrod, Blumenthal and Christian (2001) and Young (1994) separately revealed that the probability of being detected was negatively correlated with tax compliance. On the basis of the above findings and drawing from the economic deterrence theory, the following is hypothesized: 
There is a significant positive relationship between the probability of detection and tax compliance.

\section{Tax Complexity and Tax Compliance}

Complexity does arise when the relevant tax authorities try to improve the equity of the tax system and, at the same time, reduce its ambiguity (McKercher, Ingraham \& Karlinsky, 2005). Theoretically, a simple job can easily be accomplished against tedious or complex undertakings. In relation to tax compliance, past studies (e.g. Cox and Eger, 2006; Gambo, Mas'ud, Nasidi \& Oyewole, 2014; McKerchar, 2003) discovered a statistically significant negative relationship between tax complexity and tax compliance. Conversely, Kirchler, Niemirowski and Wearing, (2006) found a positive relationship between tax complexity and tax compliance while Forest and Sheffrin (2002) failed to discover the influence of complexity on taxpayers' perception towards compliance.

Aligning with the equity theory, Fjeldstad, Schulz-Herzenberg and Sjursen (2012) stated that when the tax system is perceived to be complex, taxpayers may stand to question its fairness. As such, the more complex a tax system is, the more taxpayers do perceive the inequity of the whole system. Based on this judgment, tax complexity may portray some element of negativity on tax compliance. Hence, drawing from the tenet of the equity theory and past empirical findings, the following proposition is offered:

\section{H3 : There is a significant negative relationship between tax complexity and tax compliance.}

\section{Incentives (Positive inducement) and Tax Compliance}

A good tax system should be capable of providing the taxpayers with the needed incentives. These incentives could be in the form of positive inducement which may encourage the taxpayers to comply with the relevant tax laws and regulations, as well as the penalties or sanctions where there is a likelihood of non-compliance (Slemrod, 1992; Smith, 1992). Therefore, Richardson and Sawyer (2001) were of the view that the effectiveness of positive reinforcements should be encouraged in all aspects in order to raise compliance.

In the literature, Harju and Kosenen (2012) pointed that, the provision of adequate and better tax incentives will help in boosting the economic activities of entrepreneurs. Therefore, these positive inducements could take different forms, such as a polite and helpful service provided by the staff of the relevant tax authority, though a direct relationship between incentives (positive inducement) and tax compliance has been documented in the literature (e.g. Manaf, 2004). Meanwhile, its direct effects would further be tested in this study; this is due to the fact that the construct has witnessed less attention in the literature, especially in the African region. On the basis of the foregoing discussion and drawing from the social exchange theory, the following is hypothesized:

\section{H4 : There is a significant positive relationship between incentives (positive inducement) and tax compliance.}

\section{Tax knowledge and Tax Compliance}

There are no consistent findings related to tax knowledge and tax compliance. In particular, Milliron (1985) found a positive relationship between individual understanding of the tax laws and tax compliance. Similarly, Kasipillai and Jabbar (2003) and Kirchler, Niemirowski and Wearing (2006) separately discovered compliance rate to possess a higher magnitude of correlation with tax knowledge. In the same vein Manaf (2004) and Manaf, Hasseldine \& Hodges (2005) in a separate but related study, also revealed that knowledge and understanding of the tax are related to land taxpayers' compliance in Malaysia. The same findings were reported by Palil and Mustapha (2011) who also conducted their study in Malaysia. The authors discovered a significant relationship between tax knowledge 
and tax compliance irrespective of the variation among the respondents.

Conversely, a positive significant relationship was also documented in relation to the knowledge of the taxpayers' and tax evasion (Dubin \& Wilde, 1988; McGee, Basic \& Tyler, 2009; Ritsema, Thomas \& Ferrier, 2003). On the other hand, the absence of tax knowledge may result in an act of either tax evasion or avoidance among the taxpayers. This is supported by McKerchar (1995) who suggested that small business taxpayers are unaware of their tax knowledge shortfall, which may invariably lead to unintentional non-compliance. Hence, the present study proposes the following:

H5: There is a significant positive relationship between tax knowledge and tax compliance.

\section{Public Governance Quality and Tax Compliance}

In an attempt to relate public governance quality and tax compliance behavior, Lassen (2003) conceived that if the political good mix provided by the government is found to be distinct and unique from the ones preferred by the taxpayers, then the attractiveness of the vertical contract between the two parties will start to diminish. In the same vein, Everest - Philips and Sandall (2009) pointed out that a linkage between PGQ and taxation exists, such that quality governance is a product of a good tax system, which equally will result in a better tax system, and further make it possible to have good governance.

On the other hand, Alabade, Ariffin and Kamil (2011) also conceived a positive significant relationship between public governance quality and tax compliance of taxpayers in the FCT Abuja. The social exchange theory. which states that individuals in any commitment always direct their reciprocation or symbiotic efforts directly to the sources of any rewards they receive. Hence, the present study proposes the following:

H6 : Public governance quality is significantly and positively related to tax compliance.

\section{Perceived Service Orientation (PSO) As Potential Moderator}

Empirical studies on the effect of economic factors on tax compliance remains mixed, for instance: tax rate (e.g. Allingham \& Sandmo, 1972; Alm, Jackson \& McKee, 1992; Barbuta - Misu, 2011; Chau \& Leung, 2009); probability of detection ( Kirchler, 2007; Palil \& Mustapha, 2011; Stefura, 2012), and tax complexity (Forest \& Sheffrin, 2002; Saad, 2014). Psychological factors, for instance: incentives (e.g. Feld, Frey \& Torgler, 2006; Manaf, 2004); tax knowledge (Kasipillai \& Jabbar, 2003; Palil \& Mustapha, 2011; Saad, 2014), and public governance quality (Alabede, Ariffin \& Kamil, 2011). In the same vein, either individual or firm compliance cannot be entirely explained by the influence of economic factors alone.

Therefore, on the basis of the mixed findings reported on the relationship between these factors, it appears that a moderator needs to be introduced. Even though, Cuccia (1994) discusses the effects of non-economic factors and other contextual features, he notes that they often may moderate the influence of economic models. Hence, this paper integrates perceived service orientation to contribute to a better understanding of the conflicting findings concerning these relationships and tax compliance, because service orientation was conceived as the attitude to be helpful, thoughtful, considerate and cooperative (Hogan Hogan, \& Busch, 1984). It is expected that if services are adequately provided to the taxpayers, it will help in reducing the climate of deterrence that exists between the taxpayers and the relevant tax authorities. Hence, the following hypothesis is offered:

$H 7$ : Perceived service orientation will moderate the relationship between economic factors, psychological factors and tax compliance.

\section{Methods}

\section{Sample Design and Data Collection}

The population of this study consisted of 472 SME owners /managers in Kaduna and Kano States, in north - west, Nigeria. The study 
employed the stratified random sampling technique in according to the the Krejcie and Morgan (1970) sample size selection table. In line with Krejcie and Morgan (1970) sample selection table, a representative sample size of 214 was chosen from a population of 472 SMEs owners with $\pm 5 \%$ and $95 \%$ precision and confidence levels. In order to compensate for the non-response rate, $50 \%$ was added to the sample size as recommended by Salkind (1997). Therefore, 321 SMEs owners/managers constituted the sample size of this study. Out of the 450 copies of questionnaires distributed to the respondents, only 287 copies were completed and returned. However, 6 questionnaires were badly filled and were discarded, which reduced our usable questionnaires to 281 representing $61 \%$ valid response rate.

\section{Participants}

The participants were 281 SME owners/ managers. Of these 281 respondents, $55 \%$ were male, while the remaining $45 \%$ were female. This is actually a fair representation of both genders taking into account of at least $60 \%$ and $40 \%$ of the population in the two States covered in the study were male and female respectively. In terms of age distribution, $20.6 \%$ of the respondents were less than 30 years old and $44.5 \%$ were between 31 to 40 years old. Those respondents who were between 41 to 50 years old represented $28.1 \%$ of the total respondents, while the remaining $6.8 \%$ of the respondents were above 50 years old.

\section{Operational Measures}

The study under review adapted some of its measurement scales, while the rest were adopted from past studies to measure all the eight constructs. Furthermore, all the constructs in the research framework were based on reflective item scales. Minor adjustments were also made in terms of the wording so as to suit the context of the study. In order to ensure a flawless questionnaire, the measurement scales were also pre-tested by experts both in Malaysia and Nigeria for clarity and understanding of the scale items. All the response options were anchored on a 5-point Likert scale, ranging from $1=$ strongly disagree to $5=$ strongly agree with the exception of the tax knowledge items, which were measured on a 3 - point scale, ranging from 1 = I don't know; 2 = No; 3 = Yes.

\section{Tax compliance behavior (TCB)}

In the context of this study, tax compliance was operationalized as the willingness and ability of the taxpayers to obey the tax laws, declare their actual income and pay the right amount of taxes on the due date to the appropriate relevant authority or jurisdiction (Ayuba, Saad \& ariffin, 2016). It was measured using 15 items, adapted from Yankelovich and White (1984). The scale has been discovered to be reliable as documented by Richardson (2005).

\section{Tax rate $(T R)$}

Tax rate is defined as a percentage of taxes to be paid to the relevant tax authorities. It is operationalized in this study as a percentage of taxes to be paid to the relevant tax authorities. It was assessed with a 6 - item scale (Gilligan \& Richardson, 2005). These items have been shown to be reliable and valid for measuring tax rates. Thus, respondents were asked to indicate their responses with the statements relating to the tax rates.

\section{Probability of detection (PD)}

Probability of detection is defined as the likelihood of the relevant tax authorities uncovering an individual's noncompliance and seeking to remedy the evasion (Chau \& Leung, 2009). In this study, it is operationalised as the likelihood that the relevant tax authorities would uncover an individual's non-compliance. It was measured by 8 hypothetical scenario item statements developed by Wenzel (2004a) which were adapted for this research. These items have been shown to be reliable and valid (Alabede, 2012). In the same vein, the items were shown to possess adequate internal consistency (the Cronbach alphas ranged from 0.70 to 0.91 ) (Alabede, 2012). 


\section{Tax complexity $(\mathrm{TC})$}

Complexity of the tax system can simply be referred to as the process of improving the equity of the tax system which in turn reduces its ambiguity by the relevant tax authorities (McKercher, Ingraham \& Karlinsky, 2005). It is operationalized as a process where the relevant tax authorities tried to improve the equity of the tax system as well as reduce its ambiguity at the same time. Tax complexity is measured with a 7 - item scale (Saad, 2011). Hence, items to measure tax complexity were adapted from Saad (2011). Furthermore, the scale has adequate internal consistency which is within the required threshold of 0.70 .

\section{Incentives (positive inducement) (IPI)}

Incentives are seen as a form of positive inducement which encourages taxpayers to comply with the relevant tax laws and regulations, as well as the penalties or sanctions where the likelihood of noncompliance exists (Slemrod, 1992; Smith, 1992). It is operationalized as monetary rewards in the form of monetary incentives for timely filing, as well as other forms of incentives to the taxpayers who comply with the tax laws and regulations in relation to tax payment. The construct was assessed with a 2 - item scale developed by Manaf (2004) and adapted for this study.

\section{Tax knowledge (TK)}

Tax knowledge can be defined as the ability of the taxpayer to easily understand the tax laws and regulations in order to fulfill their tax statutory obligations (Loo et al., 2009). In this study, tax knowledge is operationalized as the ability of the taxpayer to fully understand the tax law and compute his / her tax liability. It was measured with by 6 items developed by Eriksen and Fallan (1996) and Kasipillai (1997) which was adapted in the course of this study. The items have been shown to be valid and reliable in measuring the taxpayers' knowledge (Alabede, 2012; Kasipillai, 1997).

\section{Public governance quality $(P G Q)$}

Public governance quality can be defined as the provision of efficient necessary quality political goods by the government to the taxpayers (Rotberg, 2005). It is operationalized as the efficient provision of desired public goods and services by the government to the taxpayers. In the context of this study, PGQ was measured with a 13 - item scale developed by Alabede, Ariffin and Kamil (2011). The scales have been were discovered to be reliable and valid for measuring governance quality.

\section{Perceived service orientation (PSO)}

Perceived service orientation can be defined as the attitude to be helpful, thoughtful, considerate and cooperative (Hogan, Hogan \& Busch, 1984). It is operationalized as a chance to increase trust and confidence, through the possibility of facilitating cooperation among the citizens in public administration and governance. Perceived service orientation was measured with the average of a 5 - item scale from the Gangl, Muehlbacher, de Groot, Goslinga, Hofmann, Kogler, and Kirchler (2013) perceived service orientation scale. Participants were asked to indicate their responses on a five point Likert scale ranging from $1=$ completely disagree to 5 $=$ completely agree .

\section{Results}

In this study the, Partial Least Square (PLS) path modeling was employed for the purpose of estimating the parameters. In achieving the targeted results, the SmartPLS $2.03 \mathrm{M}$ path modeling software application developed by Ringle, Wende and will (2005) was employed. In the light of the above, this study adopted a two-step process in evaluating the report of the PLS-SEM path results as suggested by Henseler, Ringle and Sinkovics (2009). The two-step process employed in this study include: (a) measurement or inner model assessment, and (b) the assessment of a structural or outer model.

\section{Measurement or Inner Model}

In evaluating and assessing the construct validity, we followed Anderson and Gerbing's (1988) two-step modeling approach. In the 
process of following their recommendation, the convergent validity and reliability were assessed first, followed by the discriminant validity, and finally the internal consistency reliability of the study constructs as shown in Table 1 and Table 2 respectively. Using Hair, Black, Babin,
Anderson, and Tatham (2006) as bases, construct validity was ascertained if the indicator loadings were above 0.7 , composite reliability was greater than 0.7 , the average variance extracted was greater than 0.5 .

Table 1

Result of Measurement Model

\begin{tabular}{|c|c|c|c|c|}
\hline Construct & Items & Loadings & $\begin{array}{l}{ }^{\mathrm{a}} \text { Composite } \\
\text { reliability }(\mathrm{CR})\end{array}$ & $\begin{array}{c}{ }^{\mathrm{b}} \text { Average variance extracted } \\
\text { (AVE) }\end{array}$ \\
\hline \multirow[t]{2}{*}{ Incentives } & IPI01 & 0.90 & 0.83 & 0.71 \\
\hline & IPI02 & 0.78 & & \\
\hline \multirow[t]{3}{*}{$\begin{array}{l}\text { Probability of } \\
\text { detection }\end{array}$} & PD01 & 0.81 & 0.86 & 0.67 \\
\hline & PD02 & 0.89 & & \\
\hline & PD03 & 0.74 & & \\
\hline \multirow[t]{3}{*}{$\begin{array}{l}\text { Public governance } \\
\text { quality }\end{array}$} & PGQ12 & 0.78 & 0.82 & 0.61 \\
\hline & PGQ03 & 0.82 & & \\
\hline & PGQ07 & 0.74 & & \\
\hline \multirow[t]{3}{*}{$\begin{array}{l}\text { Perceived service } \\
\text { orientation }\end{array}$} & PSO1 & 0.75 & 0.75 & 0.50 \\
\hline & PSO3 & 0.71 & & \\
\hline & PSO4 & 0.65 & & \\
\hline \multirow[t]{2}{*}{ Tax complexity } & $\mathrm{TC} 01$ & 0.78 & 0.82 & 0.70 \\
\hline & TC04 & 0.88 & & \\
\hline \multirow[t]{10}{*}{$\begin{array}{l}\text { Tax compliance } \\
\text { behaviour }\end{array}$} & TCB01 & 0.77 & 0.94 & 0.64 \\
\hline & TCB11 & 0.79 & & \\
\hline & TCB13 & 0.82 & & \\
\hline & TCB14 & 0.75 & & \\
\hline & ТСВ02 & 0.86 & & \\
\hline & TCB04 & 0.79 & & \\
\hline & TCB06 & 0.82 & & \\
\hline & ТCB07 & 0.76 & & \\
\hline & ТCB08 & 0.74 & & \\
\hline & ТСB09 & 0.87 & & \\
\hline \multirow[t]{3}{*}{ Tax knowledge } & TK01 & 0.55 & 0.85 & 0.68 \\
\hline & TK02 & 0.93 & & \\
\hline & TK05 & 0.93 & & \\
\hline
\end{tabular}




\begin{tabular}{lcccc}
\hline Construct & Items & Loadings & $\begin{array}{c}{ }^{\mathrm{a} C} \text { Composite } \\
\text { reliability }(\mathrm{CR})\end{array}$ & $\begin{array}{c}{ }^{\mathrm{b}} \text { Average variance extracted } \\
\text { (AVE) }\end{array}$ \\
\hline Tax rate & TR01 & 0.89 & 0.89 & 0.64 \\
& TR02 & 0.89 & & \\
& TR04 & 0.67 & & \\
& TR05 & 0.73 & & \\
& TR06 & 0.78 & & \\
\end{tabular}

Note:PD04, PD05, PD06, PD07, PD08, PGQ01, PGQ02, PGQ04, PGQ05, PGQ06, PGQ08, PGQ09, PGQ10, PGQ11, PGQ13, PSO2,PSO5, TC02, TC03, TC05, TC06, TC07, TCB03, TCB05, TCB10, TCB12, TCB15, TK03, TK04, \& TR03 were deleted because of low loadings of less than 0.50 ; ${ }^{a}$ Composite Reliability $(\mathrm{CR})=$ (square of the summation of the factor loadings)/[(square of the summation of the factor loadings) + (square of the summation of the error variances)]; bAverage Variance Extracted $(\mathrm{AVE})=($ summation of the square of the factor loadings $) /[$ (summation of the square of the factor loadings) + (summation of the error variances)].

In meeting the conditions for achieving the measurement model, the discriminant validity of the study constructs was evaluated as shown in Table 2. Following Fornell and Lacker's
(1981) recommendation, the average variance shared between each construct and its measures should exceed the variance shared between the construct and the other constructs.

Table 2

Latent Variable Correlations and Square Roots of the Average Variance Extracted

\begin{tabular}{lcccccccc}
\hline \multicolumn{1}{c}{ Variables } & INC & PD & PGQ & PSO & TC & TCB & TK & TR \\
\hline INC & 0.84 & & & & & & & \\
PD & 0.10 & 0.82 & & & & & & \\
PGQ & 0.11 & 0.16 & 0.78 & & & & & \\
PSO & 0.04 & 0.11 & 0.02 & 0.70 & & & & \\
TC & -0.12 & -0.01 & -0.04 & -0.01 & 0.83 & & & \\
TCB & 0.79 & 0.19 & 0.20 & 0.11 & -0.14 & 0.80 & & \\
TK & -0.10 & -0.01 & 0.04 & -0.30 & -0.00 & -0.10 & 0.82 & \\
TR & 0.00 & 0.05 & 0.01 & -0.05 & -0.01 & 0.02 & 0.01 & 0.80 \\
\hline
\end{tabular}

Note: Entries shown in bold represent the square root of the average variance extracted.

As revealed in Table 2, the absolute correlation values for each of the study constructs is less than the square root of the average variance extracted. Thus, an adequate discriminant validity of the constructs is reached (Hair, Black, Babin \& Anderson, 2010).

\section{Structural or Inner Model}

The result of the structural model was assessed, taking into consideration the 281 cases and 5000 bootstrap samples as presented in Table 3. In particular, the $\mathrm{t}$ - values were used in interpreting the hypothesized relationships. Considering hypothesis1, which hypothesized a significant negative relationship between tax rates and tax compliance, the result (Table 3, Figure 2) showed no significant relationship between tax rates and tax compliance $(\beta=0.00, \mathrm{t}=0.10, \mathrm{p}>$ $0.10)$. Thus, this hypothesis was not supported. On the influence of the probability of detection, the result for hypothesis 2 , which predicted a 
significant positive relationship between the probability of detection and tax compliance, indicated that the probability of detection had a significant positive relationship with tax compliance $(\beta=0.09, \mathrm{t}=3.50, \mathrm{p}<0.01)$. Thus finding indicated full support for hypothesis (H2).

With regards to the influence of tax complexity, hypothesis (H3), which hypothesised a significant negative relationship between tax complexity and tax compliance, was also supported because the estimates as shown (Table 3, Figure 2) were significant $(\beta=-0.03, \mathrm{t}=1.27, \mathrm{p}<0.10)$. In terms of incentives (positive inducement) on tax compliance, the result (Table 3, Figure 2) indicated that incentives (positive inducement) had a significant positive relationship with tax compliance $(\beta=0.74, \mathrm{t}=28.37, \mathrm{p}<0.01)$. Therefore, hypothesis (H4) was fully supported. However, for hypothesis (H5) on the influence of tax knowledge, the result (Table 3, Figure 2) showed no significant negative relationship between tax knowledge and tax compliance $(\beta=-0.01, t=0.19, p>0.10)$. As such, hypothesis (H5) was not supported. As presented in Table 2, a significant positive relationship between public governance quality and tax compliance $(\beta=0.09, \mathrm{t}=2.93, \mathrm{p}<0.01)$ was found, indicating full support for hypothesis (H6).

Regarding the interacting effect of perceived service orientation on the relationship between economic factors, psychological factors and tax compliance as hypothesized in (H7), as expected, the results shown in Table 3 , indicated that the interaction terms representing tax rate $\mathrm{x}$ perceived service orientation $(\beta=0.06, \mathrm{t}=$ $1.43, \mathrm{p}<0.10)$ was statistically significant. In the same vein, the interacting terms between the incentives (positive inducement) $\mathrm{x}$ perceived service orientation $(\beta=0.10, t=1.76)$ was statistically significant. However, as captured in Hypothesis 7, it could be recalled that perceived service orientation will moderate the relationship between probability of detection, tax complexity, tax knowledge, and public governance quality and tax compliance. The results (Table 3) suggest that the interaction terms representing the probability of detection x perceived service; tax complexity $\mathrm{x}$ perceived service orientation; tax knowledge $\mathrm{x}$ perceived service orientation; public governance quality $\mathrm{x}$ perceived service orientation were not statistically significant (see Table 3).

Table 3

Path Coefficients and Hypotheses Testing

\begin{tabular}{lcccl}
\hline Relationship & Beta - values & Standard error & T statistics & Decision \\
\hline INC -> TCB & 0.74 & 0.03 & $28.37 * * *$ & Supported \\
INC * PSO -> TCB & 0.10 & 0.06 & $1.76^{* *}$ & Supported \\
PD -> TCB & 0.09 & 0.03 & $3.50 * * *$ & Supported \\
PD * PSO -> TCB & -0.05 & 0.05 & 0.90 & Not supported \\
PGQ -> TCB & 0.09 & 0.03 & $2.93 * * *$ & Supported \\
PGQ * PSO -> TCB & 0.04 & 0.04 & 0.94 & Not supported \\
TC $->$ TCB & -0.03 & 0.03 & $1.27 *$ & Supported \\
TC * PSO -> TCB & -0.02 & 0.05 & 0.48 & Not supported \\
TK -> TCB & -0.01 & 0.03 & 0.19 & Not supported \\
TK * PSO -> TCB & -0.06 & 0.07 & 0.95 & Not supported \\
\hline
\end{tabular}

(continued) 


\begin{tabular}{lcccc}
\hline Relationship & Beta - values & Standard error & T statistics & Decision \\
\hline TR $->$ TCB & 0.00 & 0.03 & 0.10 & Not supported \\
TR * PSO -> TCB & 0.06 & 0.04 & $1.43^{*}$ & Supported \\
\hline
\end{tabular}

Note: $* * *$ Significant at 0.01 (1-tailed), **significant at 0.05 (1-tailed), *significant at 0.1 (1-tailed).

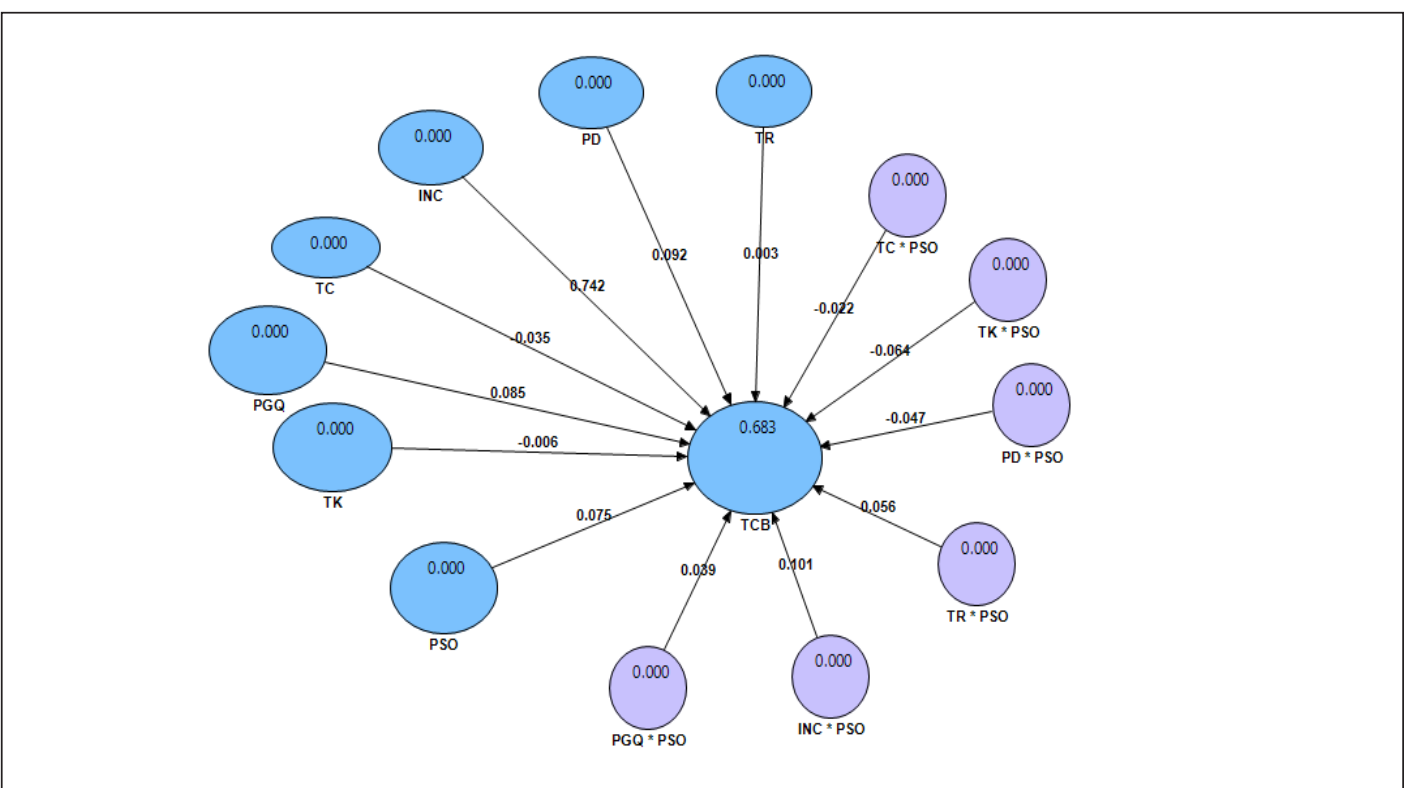

Figure 2. Results of the structural model analysis

\section{Discussion}

This study examined the direct effect of economic and, psychological factors, as well as the moderating effect of perceived service orientation in relation to the tax compliance of Nigerian SMEs. Hypothesis (H1) was contrary to our expectation because an insignificant relationship was discovered. Anyway, the finding could align with the tenet of the economic deterrence theory which posits that, taxpayers' behaviour is influenced by factors such as: the tax rate in ascertaining the rewards of evasion or noncompliance; the probability of detection, and penalties for the crime or fraud which help in determining the costs (Allingham \& Sandmo 1972; Becker, 1968). One plausible explanation for the present findings may be related to economic, cultural, demographic, and business orientations of the respondents who belong to a highly under - developed economy. This finding is consistent with Modugu and Anyaduba (2012) who failed to discover either a positive or a negative relationship on tax compliance in one of the African countries. In their study, they did not proceed to explain why no significant relationship exists between the two constructs.

As expected, the findings offer support for hypothesis 2 . Most importantly and in the context of this study, the current findings significantly agree with previous studies (Alm, 1991; Carnes \& Englebrecht, 1995; Eisenhauer, 2008) that found the probability of detection to significantly and positively relate to tax compliance. This finding, like the previous positive findings is also consistent with the tenets of the economic deterrence theory as propounded by Allingham and Sandmo (1972). Hypothesis (H3) which asserted a significant negative relationship between tax complexity and tax compliance was accepted. The finding is consistent with (Cox 
\& Eger, 2006) who found tax complexity to contribute to an increase in tax non-compliance. The negativity of its association could be aligned to the tenets of the equity theories of Adams (1965) and Fjeldstad, Sjursen and Ali (2012), which state that, when the tax system is perceived to be complex, taxpayers may stand to question its fairness.

Consistent with hypothesis (4), a significant positive relationship between incentives (positive inducement) and tax compliance was found. This finding also lends support to the social exchange theory (Blau, 1964). This result suggests that individuals are psychologically indebted and thus forced to pay back the benefits they received in material or non-material form to the person that benefited them. This result also agrees with Alm, Jackson and MacKee (1992a), and Trivedi, Shehata and Mestelman (2004) who found a significant positive relationship between positive incentives and tax compliance. The importance of this finding is not far fetched, because the provision of adequate and better tax incentives will help in boosting the economic activities of entrepreneurs.

For of hypothesis (5), unexpectedly, the result failed to support the proposed hypothesis. Specifically, the present finding is in line with Harris (1989) who found no significant direct relationship between tax knowledge and taxpayers' compliance. Consistent with this finding is McKerchar (1995) who suggested that small business taxpayers are unaware of their tax knowledge shortfall, which may invariably lead to unintentional non-compliance.

Consistent with hypothesis (H6), a significant positive relationship between public governance quality and tax compliance was found. In agreement with Blau's social exchange theory (1964), this result suggests the role of reciprocity in enforcement of compliance in social relationship. This finding could also be aligned to Torgler $(2003,2007)$ who found positive behaviour by the government to be reciprocated by the taxpayers through enhanced compliance.

It can be recalled from the previous section that perceived service orientation will moderate the relationship between tax rates, the probability of detection, tax complexity, tax knowledge, incentives, public governance quality and tax compliance as hypothesized in (H7). To our surprise, perceived service orientation only moderated the relationship between tax rate and incentives. One of the interesting aspects of this finding is that the presence of service orientation on the relationship between tax rate, incentives (positive inducement) and tax compliance made the relationship to be more positive. This is an indication that the effects of perceived service orientation had further strengthened the influence of these constructs on taxpayers' compliance, as such, it recommends that in the presence of service orientation, with an increase in tax rate as well as the provision of incentives, SMEs owners / managers are likely to be more compliant. This result come in the direction and statistical significance expected, indicating that a remarkable number of SMEs owners believe that incentives-cum-service orientation will further increase the level of compliance.

The lack of the moderating effect of perceived service orientation on the relationship between probability of detection, tax complexity, tax knowledge and public governance quality might be a result of the participants of this study not actually being motivated by the activities of the relevant tax authorities targeting at benefiting the SMEs owners / managers. The results demonstrate that service awareness does not serve as an avenue in enlightening the taxpayers towards increasing their compliance level; in essence service orientation does not stimulate the taxpayers. Even though Locke (1968) reported that if people are to be motivated to behave in a rational way, such people need to see a good reason to act in the desired direction. From the findings, it can be deduced that taxpayers' concern for perceived service orientation does not supersede their perception on the above determinants.

\section{Implications}

On the basis of the above findings and discussions, there are a few implications for 
policy-makers to take into account due of the importance of taxes to the survival of any economy. The importance of the moderating effect of perceived service orientation, which serves as the main contribution of this study, implies that authorities that are perceived as a service-oriented would yield a greater level of voluntary compliance. Furthermore, perceived service orientation and ethical reorientation could be a promising stand in reducing the likelihood of a low level of tax compliance.

There are also several limitations. Specifically, the study reported an R - squared of $68 \%$, suggesting that other variables could account for the remaining $32 \%$. Hence, future research could look at the possibility of incorporating other variables. Furthermore, this study was entirely cross - sectional where data were sourced at a point in time. To that end, inferences concerning the cause and effect nature of the study could not be ascertained with clarity. Future studies could look at the possibility of embarking on a mixedmode in order to confirm the authenticity of these findings. In the same vein, generalization of the findings could be restricted to the SMEs sector; the possibility of incorporating other sectors could be a researchable avenue.

\section{References}

Adams, J. S. (1965). Inequity in social exchange. In L. Berkowitz (Ed.). Advances in Experimental Social Psychology,. 2. New York: Academic Press.

Alabede, J. O., Ariffin, Z. Z., \& Kamil, I. (2011). Public governance quality and tax compliance behavior in Nigeria: The moderating role of financial condition and risk preference. Issues in Social and Environmental Accounting, 5(1/2), 3-24.

Alabede, J.O. (2012). An investigation of factors influencing taxpayers' compliance behaviour: Evidence from Nigeria. Unpublished $\mathrm{PhD}$ thesis. University Utara Malaysia.

Ali, M. M., Cecil, H. W., \& Knoblett, J. A. (2001). The effects of tax rates and enforcement policies on taxpayer compliance: A study of self-employed taxpayers. Atlantic Economic Journal, 29(2), 186-202.

Allingham, M., \& Sandmo, A. (1972). Income tax evasion: A theoretical analysis. Journal of Public Economics, 1(3-4), 323-338.

Alm, J. (1991). A perspective on the experimental analysis of taxpayer reporting. Accounting Review, 66(3), 577- 593.

Alm, J., Jackson, B., \& McKee, M. (1992b). Estimating the determinants of taxpayer compliance with experimental-data. National Tax Journal, 45(1), 107-114.

Alm, J., Sanchez, I., \& De Juan, A. (1995). Economic and noneconomic factors in tax compliance. Kyklos, 48(1), 3-18.

Anderson, J.C., \& Gerbing, D.W. (1988). Structural equation modeling in practice: A review and recommended two - step approach. Psychological Bulletin, 103, $411-423$.

Atawodi, O. W., \& Ojeka, S. A. (2012). Factors that affect tax compliance among small and medium enterprises in North Central Nigeria. International Journal of Business and Management, 7(12), 87-96. doi:10.5539/ijbm.v7n12p87.

Australian Tax Office. (2009). Retrieved 22 May, 2014, from http://www.ato. gov.au/corporate/content.asp?doc=/ content/00107941.htm.

Ayuba, A., Saad, N., \& Ariffin, Z. Z. (2016). Does perceived corruption moderate the relationship between economic factors and tax compliance? A proposed framework for Nigerian small and medium enterprises. Mediterranean Journal of Social Sciences, 7(1), 402 409.

Ayuba, A., Saad, N., \& Ariffin, Z. Z. (2015). Interacting role of perceived service orientation on work family conflict, fuel subsidy removal and tax compliance behaviour: Evidence from Nigerian SMEs. Asian Social Science, 11(28), 226 $-239$.

BBC News. (May 21, 2013). Google, Amazon, Starbucks: The Rise of 'Tax 
Shaming', http://www.bbc.co.uk/news/ magazine-20560359.

Becker, G. S. (1968). Crime and punishment: An economic approach. Journal of Political Economy, 76(2), 168-217.

Bergman, M. (2009). Tax evasion and rule of law in Latin America. Philadelphia: Penn State University Press.

Besancon, M. (2003). Good governance ranking: The art of measurement. Cambridge: World Peace Foundation.

Blau, P. M. (1964). Exchange and power in social life. New York: John Wiley \& Sons, Inc.

Chris, C. W., Coleen S. T., \& David, O. (2000). An expanded model of taxpayer compliance: Empirical evidence from the United States and Hong Kong. Journal of International Accounting, Auditing and Taxation, 9(2), 83-103.

Christian, C. W., \& Gupta, S. (1993). New evidence on 'secondary evasion. The Journal of the American Taxation Association, 15(1), 72-93.

Clotfelter, C. T. (1983). Tax evasion and tax rates: An analysis of individual returns. Review of Economics and Statistics 65 (3), 363-373.

Cox, S. P., \& Eger, R. J. I. (2006). Procedural complexity of tax administration: The road fund case. Journal of Public Budgeting, Accounting and Financial Management, 18(3), $259-283$.

Cuccia, A. D. (1994). The effects of increased sanctions on paid tax preparers: Integrating economic and psychological factors. The Journal of the American Taxation Association, 16(1), 41-66.

Eisenhauer, J. G. (2008). Ethical preferences, risk aversion, and taxpayer behaviour. The Journal of Socio-Economics, 37(1), 45-63.

Eriksen, K., \& Fallan, L. (1996). Tax knowledge and attitudes towards taxation; A report on a quasi-experiment. Journal of Economic Psychology, 17(3), 387-402.

Feinstein, J. S. (1991). An econometric analysis of income tax evasion and its detection. The RAND Journal of Economics, 22(1), 14. Doi: $10.2307 / 2601005$.
Fischer, C.M., Wartick, M., \& Mark, M. M. (1992). Detection probability and taxpayer compliance: A review of the literature. Journal of Accounting Literature, 11, 1- 27.

Fjeldstad, O. H., Sjursen, I. H., \& Ali, M. (2012). Factors affecting tax compliant attitude in Africa: Evidence from Kenya, Tanzania, Uganda and South Africa. Presented at: Centre for the Study of African Economies (CSAE) Conference (Vol. 18).

Forest, A., \& Sheffrin, S.M. (2002). Complexity and compliance: An empirical investigation. National Tax Journal, 55, $75-88$

Fornell, C., \& Larcker, D.F. (1981). Evaluating structural equation models with unobservable variables and measurement error. Journal of Marketing Research, 18(1), 39-50.

Gambo, E.J., Mas'ud, A., Nasidi, M., \& Oyewole, O.S. (2014). Tax complexity and tax compliance in African selfassessment environment. International Journal of Management Research \& Review, 4(5), 575 - 582.

Gangl, K., Muehlbacher, S., de Groot, M., Goslinga, S., Hofmann, E., Kogler, C., \& Kirchler, E. (2013). How can I help you? Perceived service orientation of tax authorities and tax compliance. Finanz Archiv: Public Finance Analysis, 69(4), 487-510. Doi: $10.1628 / 001522113$ X675683.

Geibart, N. (2014). Digging out the complexities of tax compliance. The Business, 32 - 33.

Gilligan, G., \& Richardson, G. (2005). Perceptions of tax fairness and tax compliance in Australia and Hong Kong: A preliminary study. Journal of Financial Crime, 12(4), 331-343.

Hai, O. T., \& See, L. M. (2011). Behavioural intention of tax non-compliance among sole-proprietors in Malaysia. International Journal of Business and Social Science, 2(6), 142-152.

Hair, J. F., Black, W. C., Babin, B. J., \& Anderson, R. E. (2010). Multivariate data analysis: A global perspective. New Jersey: Pearson Education, Inc. 
Hair, J. F., Black, W. C., Babin, B. J., Anderson, R. E., \& Tatham, R. L. (2006). Multivariate data analysis ( $6^{\text {th }}$ ed.). New Jersey, Prentice Hall.

Harju, J., \& Kosonen, T. (2012). The impact of tax incentives on economic activity of entrepreneurs (pp. 1-32).

Harris, T.D. (1989). The effect of type of tax knowledge on individuals' perceptions of fairness and compliance with the federal income tax system: An empirical study. PhD Thesis, University of South Carolina.

Henseler, J., Ringle, C.M., \& Sinkovics, R.R. (2009). The use of partial least squares path modeling in international marketing. In R.R. Sinkovics \& P.N. Ghauri (Eds.). Advances in International Marketing, 20, 277-230.

Hogan, J., Hogan, R., \& Busch, C. M. (1984). How to measure service orientation? Journal of Applied Psychology, 69(1), 167-173.

Inland Revenue Board (IRB) Malaysia. (2009). Retrieved 22 May 2014, from http:// www.hasil.gov.my.

Jackson, I.A. (1986). Amnesty and creative tax administration. National Tax Journal, 39, 317 - 323.

James, S., \& Alley, C. (2002). Tax compliance, self-assessment system and tax administration. Journal of Finance, and Management in Public Services, 2(2), 27 $-42$.

James, S., \& Alley, C. (2004). Tax compliance, self-assessment and tax administration. Journal of Finance and Management in Public Services, 2(2), 27 - 42.

Kasipillai, J. (1997). Aspect of the hidden economy and non-compliance in Malaysia. Unpublished doctoral thesis, University of New England, Armidale.

Kasipillai, J., \& Jabbar, A.H. (2003). Tax compliance attitude and behaviour; gender \& ethnicity differences of Malaysian taxpayers. The Malaysian Accountant, 1 - 7.

Kirchler, E., Niemirowski, A., \& Wearing, A. (2006). Shared subjective views, intent to cooperate and tax compliance:
Similarities between Australian taxpayers and tax officers. Journal of Economic Psychology, 27(4), 502-517.

Krejcie, R.V., \& Morgan, D.W. (1970). Determining sample size for research activities. Educational and Psychological Measurement, 30, 607-610.

Lewis, A., Carrera, S., Cullis, J., \& Jones, P. (2009). Individual, cognitive and cultural differences in tax compliance: UK and Italy compared. Journal of Economic Psychology, 30, 431-445.

Locke, E. A. (1968). Towards a theory of task motivation and incentives. Organizational Behavior and Human Performance, 3, 157-89.

Manaf, N. A. (2004). Land tax administration and compliance attitude in Malaysia (Unpublished doctoral thesis). University of Nottingham, United Kingdom.

Manaf, N. A., Hasseldine, J., \& Hodges, R. (2005). The determinants of Malaysian land taxpayers' compliance attitude. eJournal of Tax Research, 3(2), 206-221.

Mas'ud, A., Aliyu, A.A., \& Gambo, E.J. (2014) Tax rate and tax compliance in Africa. European Journal of Accounting Auditing and Finance Research, 2(3), 22 $-30$.

McBarnett, D. (2003). When compliance is not the solution but the problem: From changes in law to changes in attitude. In V. Braithwaite, Tax democracy: Understanding tax avoidance and evasion. Aldershort: Ashgate Publishing Ltd.

McKerchar, M. (2003). The impact of complexity upon tax compliance: A study of Australian personal taxpayers. Australian Tax Research Foundation.

McKerchar, M., Ingraham, L R., \& Karlinsky, S. (2005).Tax complexity and small business: A comparison of the perceptions of tax agents in the United States and Australia. Journal of Australian Taxation, 289-327.

Milliron, V. C. (1985). A behavioural study of the meaning and influence of tax complexity. Journal of the Accounting Research, 23(2), 794-816. 
Modugu, K.P., \& Anyaduba, J.O. (2014). Impact of tax audit on tax compliance in Nigeria. International Journal of Business and Social Science, 5(9), 207 $-215$.

Muhammad, A. (2012). Kano state shuts 30 schools over tax evasion. Vanguard. Kano.

Mustafa, H. H. (1997). An evaluation of the Malaysian tax administrative system and taxpayers' perceptions towards self-assessment system, tax law fairness and tax law complexity. Unpublished manuscript, Universiti Utara Malaysia, Malaysia.

New Sabah Times English. (2013). IRBM solves nearly 1.9 mil tax evasion cases in 2012.

Nur-tegin, K. D. (2008). Determinants of business tax compliance. The B.E. Journal of Economic Analysis \& Policy, 8(1), 1 - 26. doi:10.2202/19351682.1683.

Palil, M. R., \& Mustapha, A. F. (2011). Factors affecting tax compliance behaviour in self- assessment system. African Journal of Business Management, 5(33), 12864-12872. doi:10.5897/ AJBM11.1742.

Palil, M.R., Hamid, M.A., \& Hanafiah, H. M. (2013). Taxpayers compliance behaviour : Economic factors approach. Journal Pengurusan, 38, 75-85.

Paying Taxes. (2014). The global picture. A comparison of tax systems in 189 economies worldwide.

Paying Taxes. (2015). The global picture. A comparison of tax systems in 189 economies worldwide.

Pommerehne, W. W., \& Weck-Hannemann, H. (1996). Tax rates, tax administration and income tax evasion in Switzerland. Public Choice, 88(1-2), 161-170.

Richardson, G. (2005). An exploratory cross cultural study of tax fairness perceptions and tax compliance behaviour in Australia and Hong Kong. International Tax Journal, 31(1), 11 67.
Richardson, G. (2006). Determinants of tax evasion: A cross-country investigation. Journal of International Accounting, Auditing and Taxation, 15(2), 150-169. doi:10.1016/j. intaccaudtax.2006.08.005.

Richardson, M., \& Sawyer, A. (2001). A taxonomy of the tax compliance literature: Further findings, problems and prospects. Australian Tax Forum, 16(2), 137 - 320.

Ringle, C. M., Wende, S., \& Will, A. (2005). SmartPLS 2.0. Retrieved August 23, 2015 from www.smartpls.de.

Roth., J. A., Scholz, J.T., \& Dry-Witte, J. T. (1989). Taxpayer compliance: An agenda for research. Volumel. Philadelphia: University of Pennsylvania Press.

Saad, N. (2011). Fairness perceptions and compliance behaviour: Taxpayers' judgments in self-assessment environment (Unpublished doctoral thesis). University of Canberbury, Christchurch.

Saad, N. (2014). Tax knowledge, tax complexity and tax compliance: Taxpayers' view. Procedia Social and Behavioral Sciences, 109(1), 1069-1075. doi:10.1016/j.sbspro.2013.12.590.

Salkind, N. J. (1997). Exploring research (3rd ed.). Upper Saddle River, NJ: Prentice Hall.

Shekari, I. (2014). Tax evasion in Kaduna state. Premium Times.

Slemrod, J. (1985). An empirical test for tax evasion. Review of Economics and Statistics, 67(2), 232-238.

Slemrod, J. (1992). Why people pay taxes, tax compliance and enforcement. Ann Arbor: University of Michigan Press.

Slemrod, J., Blumenthal, M., \& Christian, C. (2001). Taxpayer response to an increased probability of audit: Evidence from a controlled experiment in Minnesota. Journal of Public Economics, 79(3), 455-483. doi:10.1016/S0047-2727(99)00107-3.

Smith, K.W.(1992). Reciprocity and fairness: Positive incentives for tax compliance. 
In Slemrod, J. (Ed.). Why people pay taxes: Tax compliance and enforcement. Ann Arbor, MI: University of Michigan Press: $223-250$.

Song, Y.D., \& Yarbrough, T.E. (1978). Tax ethics and taxpayer attitudes: A survey. Public Administration Review, 38(5), 442-452.

Stalans, L., \& Lind, E. A. (1997). The meaning of procedural fairness: A comparison of taxpayers' and representatives' views of their tax audits. Social Justice Research, 10, 311-331.

Stefura, G. (2011). The role played by economic and non-economic variables in the analysis of tax compliance. Review of Economic and Business Studies, 4(2), 105- 120.

Stefura, G. (2012). A new perspective on individual tax compliance: The role of the income source, audit probability and the chance of being detected. The USV Annals of Economics and Public Administration, 12(2 (16)), 192-201.

Taiwo, O., Services, R., International, P., Council, N. E., Academy, P. T., \& Faculty, D. T. (2013). An interview with Taiwo Oyedele on the tax implications of Nigeria' s rebased GDP, (May).

Tanko, M. (2014). Kaduna shuts 25 private schools, MFB over tax evasion, Punch.
Torgler, B. (2003). Tax morale: Theory and analysis of tax compliance. Unpublished doctoral dissertation, University of Zurich, Switzerland.

Torgler, B. (2005). Speaking to theorists and searching for facts: Tax morale and tax compliance in experiments. Journal of Economic Surveys, 16(5), 77 - 89.

Torgler, B., \& Schneider, F. (2009). The impact of tax morale and institutional quality on the shadow economy. Journal of Economy Psychology, 30, 228-245.

Torgler., B. (2007). Tax compliace and tax morale. Cheltenham: Edward Elgar Publishing Ltd.

Trivedi, V. U., Shehata, M., \& Mestelman, S. (2004). Attitudes, incentives, and tax compliance. Department of Economics, McMaster University.

Wenzel, M. (2004a). The social side of sanctions: Personal and social norms as moderators of deterrence. Law and Human Behaviour, 28(5), 547-567.

Yankelovich, S., \& White, C. (1984). Survey of taxpayer attitudes. Washington DC. doi:20224.

Young, J.C. (1994). Factors associated with non-compliance: Evidence from the Michigan tax amnesty program. Journal of American Taxation Association, 16(2), 82-105. 